\title{
Limitations of the Standard Procedure for the Evaluation of Marble and Limestone for Use in Construction: A Critical Analysis and Proposal for Modification
}

\author{
F. Ortega-Díaz, P. Aparicio and E. Galán
}

Dpto. Cristalografía, Mineralogía y Química Agrícola. Facultad de Química. Universidad de Sevilla Apdo. 553, 41071, Sevilla, Spain

Corresponding author: P. Aparicio, e-mail: paparicio@us.es

\begin{abstract}
The selection of natural stone for each specific use must be based on determinations which assess their technical quality and ensure their suitability for the environment in which they will be utilized. Among the criteria to be considered, a petrographic characterization is basic to deduce the behaviour of the stone to external agents. Current European regulations for the valuation and use of a stone present serious constraints in connection with the petrographic characterization and with the definition of some of the technological tests, which can endanger the suitability of a stone for use in construction. Two commercial limestones and one marble, are studied following the existing European Standards, to explain reasonably the behavior of these materials and deduce the most appropriate uses. Finally the results lead to certain recommendations to modify existing regulations.
\end{abstract} $\begin{array}{ll}\text { Keywords: } & \text { natural stone, European Standards revision, physical properties, petrographic characterization, technological characteri- } \\ \text { zation }\end{array}$ 


\section{Introduction}

Natural stone, despite being one of the oldest construction materials, has not lost its importance today, especially for finished work such as indoor or outdoor pavement, walls and other decorative surfaces. Structural stone, by contrast, is used on rare occasions because it has been replaced by reinforced concrete.

The market for natural stone [1] has great significance in the world economy. Spain, in particular, occupies a prominent place, being the third-place world producer of natural stone with a total production in 2,009 equal to 450 million euros, and is second in the world production of marble.

In most cases the choice of natural stone is determined by purely aesthetic, decorative or ornamental reasons, rather than on criteria linked to their suitability for the environment in which they are going to be utilized. Stone petrophysical and other technological features should determine their use (Table 1) [2]. Establishing standards for this evaluation will help in choosing the stone that is most appropriate for the environment of use without compromising the aesthetic aspect, thus ensuring quality within the national and international markets.

The European Committee for Standardization (CEN) (www.cen.eu) provides a platform for the development of European Standards and other technical specifications for natural stone and many other products. CEN's 30 national members work together to develop voluntary European Standards (ENs). These standards have a unique status, since they also are national standards in each of the 30 member countries. With regard to Natural Stone the two basic standards are:

\section{EN 12440}

(Natural Stone. Denomination Criteria) [3]. The object is to unify the criteria for description of varieties of Natural Stone, maintaining the traditional names and introducing terms related to their petrology, color, distinguishing characteristics and origin.

\section{EN 12670}

(Natural stone terminology) [4]. This section defines the terminology recommended for the scientific and technical nomenclature, the methods of testing and the classification of the Natural Stone.

The tests to be performed on the natural stone can be divided into two well differentiated groups:

1. Tests for classifying and characterizing the rock, which include petrographic description and the determination of certain properties, such as water absorption by capillarity, resistance to compression, real and bulk density, and total and open porosity.

2. Trials to assess the stone for its ornamental use in construction. Among these are frost resistance, resistance to salt crystallization, resistance to ageing by $\mathrm{SO}_{2}$, and resistance to ageing by thermal shock.

Table 1: Relative importance of technological characteristics of natural stone in relations with its application in construction [after 2]

\begin{tabular}{|c|c|c|c|c|c|}
\hline \multirow{2}{*}{$\begin{array}{l}\text { Technological } \\
\text { characteristics }\end{array}$} & \multicolumn{2}{|c|}{ Walls } & \multicolumn{2}{|c|}{ Pavements } & \multirow{2}{*}{ Step stai } \\
\hline & Indoor & Outdoor & Indoor & Outdoor & \\
\hline Petrographic description & 1 & I & I & I & I \\
\hline Chemical analysis & $\mathrm{PI}$ & $\mathrm{PI}$ & $\mathrm{PI}$ & $\mathrm{PI}$ & $\mathrm{PI}$ \\
\hline Bulk density & 1 & 1 & 1 & 1 & 1 \\
\hline Water absorption & $\mathrm{PI}$ & I & $\mathrm{PI}$ & I & $\mathrm{PI}$ \\
\hline Uniaxial compressive strength & $\mathrm{PI}$ & I & $\mathrm{PI}$ & $\mathrm{I}$ & I \\
\hline Flexural strength & $\mathrm{PI}$ & 1 & 1 & 1 & $\mathrm{VI}$ \\
\hline Frost resistance & - & $\mathrm{VI}$ & - & $\mathrm{VI}$ & - \\
\hline Thermal shock resistance & $\mathrm{PI}$ & VI & $\mathrm{PI}$ & $\mathrm{VI}$ & I \\
\hline $\mathrm{SO}_{2}$ Resistance & - & I & - & I & - \\
\hline Anchorage resistance & $\mathrm{I}$ & $\mathrm{VI}$ & - & - & - \\
\hline Carbonate content & - & - & - & - & - \\
\hline
\end{tabular}


Once the desired natural stone is demonstrated to have the proper technological features, another series of tests should be conducted before putting it into use. These are completely independent of the characterization tests, but essential for utilization. They include testing the dimensional variability of the pieces to use, the parallelism and flatness of the faces, the surface finish, etc.

The purpose of this work is to determine whether the existing European standards are sufficient to deduce the suitability of a stone for a particular use, or, whether a revision and extension of the standards is needed. Three types of commercial stones have been studied following the European Standards and after some modifications to obtain a more accurate assessment of their potential uses and behavior at work. From the results obtained a criticism of the current standards for natural stone, particularly for marble and limestone, is presented.

\section{Experimental}

Three types of rocks, provided directly by the suppliers, have been selected for this study. Commercially they are called: (a) "Macael white marble" (MB), (b) "Ivory cream marble" (MC), (c) "Estepa limestone "(CE). The most common use of these rocks is in-door and out-door use, as pavement and walls.

The characterization of each stone was accomplished with a petrographic study (chemical, mineralogical and textural), and the technological tests. Ten specimens with dimensions of 100/50/50 mm have been prepared for the MB and CE stones, and $100 / 50 / 45 \mathrm{~mm}$ for the MC. For MC, $45 \mathrm{~mm}$ was used because this is the maximum thickness of the commercially available plates. The specimens were placed in a $105^{\circ} \mathrm{C}$ oven for at least seventy-two hours before making any test.

Petrographic characterization was performed according to the Standard Reference [5] based on a macroscopic visual description and microscopic determination of mineralogy and texture [6].

For the mineralogical and textural study a PACISA, S. A., polarizing light microscope was used. The major element chemical composition ( $\mathrm{Si}, \mathrm{Al}, \mathrm{Fe}$, $\mathrm{Mg}, \mathrm{Ca}, \mathrm{Na}, \mathrm{K}, \mathrm{P}, \mathrm{S}$ ) was determined by XRF, with an AXIOS instrument. Data for XRD determination of the minerals present were obtained with a Bruker Model D8 Advance Diffractometer, operated with the following measuring conditions; $40 \mathrm{KV}, 30 \mathrm{ma}$, $0.02^{\circ} 2 \theta$ step, step time $2 \mathrm{sec}$, and interval of $3-70^{\circ}$ $2 \theta$. The samples were run in a side-loading holder to minimize preferred orientation and mineral abundances were quantified using mineral intensity factors (MIR) with respect to corundum (7).

The bulk and real density were determined in accordance with UNE 1936: 2007 [8]. The measurement of the dry mass was determined with a balance having a precision of $\pm 0.01 \mathrm{~g}$, and the specimen dimensions were measured with a caliper having a precision of $\pm 0.05 \mathrm{~mm}$. The density of water used in the calculation was $0.998 \mathrm{gr} / \mathrm{cm}^{3}$ at $20^{\circ} \mathrm{C}$. The real density was calculated by the relationship between the mass of the sample, dried and crushed, and the volume of liquid displaced by the mass, using the method $\mathrm{A}$ (pycnometer) described in the standard [8].

The open porosity is the ratio between the volume of pores and the apparent volume of the sample. To calculate the volume of pores the previously weighed dry specimens were submerged in deionized water at atmospheric pressure for 48 hours. The specimens were removed from the bath and dried superficially with a damp cloth prior to reweighing. The weight difference between the dry specimen and the water saturated one, divided by the density of water will give the volume $\left(\mathrm{cm}^{3}\right)$ of pores, which can be linked with the bulk density. Total porosity was calculated as the ratio (percentage) between the volume of the pores (open plus closed) and the apparent volume of the specimen [8].

Table 2: Chemical analysis (wt \%)

\begin{tabular}{|l|c|c|c|c|c|c|c|c|c|c|c|}
\hline Sample & $\mathbf{S i O}_{\mathbf{2}}$ & $\mathbf{A l}_{\mathbf{2}} \mathbf{O}_{\mathbf{3}}$ & $\mathbf{F e}_{\mathbf{2}} \mathbf{O}_{\mathbf{3}}$ & $\mathbf{M g O}$ & $\mathbf{C a O}$ & $\mathbf{N a}_{\mathbf{2}} \mathbf{O}$ & $\mathbf{K}_{\mathbf{2}} \mathbf{O}$ & $\mathbf{P}_{\mathbf{2}} \mathbf{O}_{\mathbf{5}}$ & $\mathbf{S O}_{\mathbf{3}}$ & I.L. & TOTAL \\
\hline MB & n.d. & 0.03 & 0.05 & 0.60 & 54.62 & 0.03 & 0.01 & 0.01 & 0.02 & 42.82 & 98.08 \\
\hline MC & 0.23 & 0.11 & 0.01 & 0.10 & 55.08 & 0.02 & 0.02 & 0.01 & 0.02 & 42.46 & 98.03 \\
\hline CE & n.d. & 0.01 & 0.17 & 0.17 & 54.67 & 0.01 & 0.00 & 0.03 & 0.03 & 43.12 & 98.06 \\
\hline
\end{tabular}

n.d.: Not detected. I.L.: Ignition loss 
Water absorption by capillarity was determined by the increment in mass over time according to Standard UNE 1925:1999 [10]. Dry specimens were weighed and immersed to a depth of $3 \pm 1 \mathrm{~mm}$ in deionized water. At preselected times $(1,3,5,10$, $15,30,60,180,480,1440,2880$ and 4320 minutes), they were removed, partially dried, weighed and then returned to the tank of water. The ratio of water absorption (A) expressed in $\mathrm{kg} / \mathrm{m}^{2} \mathrm{~s}^{0,5}$, was calculated following the directions in the Appendix to the Standard [9].

A ZUPECAR press with $120 \mathrm{~kg} \cdot \mathrm{cm}^{-2}$ of load capacity and a loading speed of $1 \mathrm{MPa} / \mathrm{s}$ (approximately), as well as a caliper with $\pm 0.05 \mathrm{~mm}$ precision for geometrical determinations was used for the determination of uniaxial compressive strength, according to UNE 1926:2006 [10].

For resistance to salt crystallization, UNE 12370:1999 [11], the specimens were placed in a bath that covered them with a centimetre of a $14 \mathrm{wt} \%$ sodium sulphate decahydrate solution and cycled through wetting and drying cycles. Each cycle included $2 \mathrm{~h}$ submerged in the solution, $20 \mathrm{~h}$ drying in a kiln, and $2 \mathrm{~h}$ cooling. This cycle was repeated 15 times and the specimen was washed carefully with water and weighed after drying to determine the weight percentage change in the specimen.

For the determination of frost resistance, UNE 12371:2011 [12], each cycle consisted of immersion of the specimen in water for 6 hours, followed by a period of freezing for $6 \mathrm{~h}$. The total number of cycles was 15 . After the 15 cycles, all sides and edges were visually examined and their appearance classified according to the following scale: 0 ) Intact specimen; 1) Minimal damage that did not compromise the integrity of the specimen; 2) One or several minor cracks $(\leq 0.1 \mathrm{~mm}$ height $)$, or removal of small fragments ( $\leq 30 \mathrm{~mm}^{2}$ per fragment); 3 ) One or several cracks, holes, or removal of fragments larger than defined in section 2, or alteration of the material in streaks; and 4) Specimen with big cracks or broken into two or more pieces or disintegrated.

The determination of resistance to ageing by $\mathrm{SO}_{2}$, UNE 13919: 2002 [13] was accomplished by placing the specimens above solutions of sulfurous acid in a closed container. Two different concentration solutions were used: i) solution A. - $500 \mathrm{ml}$ of $\mathrm{H}_{2} \mathrm{SO}_{3}$ per $150 \mathrm{ml}$ of deionized water; (ii) solution B. - $150 \mathrm{ml}$ of $\mathrm{H}_{2} \mathrm{SO}_{3}$ for $500 \mathrm{ml}$ of deionized water. The dry specimens were weighed and soaked in deionized water for 24 hours before starting the experiment. One specimen of each type of stone was then suspended $10 \mathrm{~cm}$ above the acid solution, the container closed and the specimen allowed reacting for 21 days. The variation in the appearance, particularly the composition and location of deposits, was investigated by X-ray microfluorescence ( $\mu-X R F)$, with an Eagle lll EDAX instrument, with Rh anticathode and detector of X-ray scattered energies.

Finally, for determining of resistance to ageing by thermal shock UNE 14066:2003 [14], each sample was studied during 20 heating-cooling cycles. Each cycle included $18 \mathrm{~h}$ in oven at $105 \pm 5^{\circ} \mathrm{C}$ followed by $6 \mathrm{~h}$ submerged in deionized water at a temperature of $20 \pm 5^{\circ} \mathrm{C}$. After this cycle was determined, the weight and the specimens were visually examined to determine the presence of oxidation surface, colour changes, swelling, fractures, scaling, etc.

Results obtained have been discussed in order to determine the most suitable use of each rock according to the relative importance of each test in relation with the use (Table 1) proposed by Bustillo and Calvo (2005) [2].

\section{$3 \quad$ Results and Discussion}

\subsection{Petrographic Characterization}

The "Macael white marble" (MB) is white with some minor gray streaks. The average size is approximately 2 to $3 \mathrm{~mm}$ with a very uniform grain-size distribution. The material is compact without apparent cracks. Under the optical microscope a granuloblastic texture typical of marble is observed. The crystals of calcite are well-developed, and fractured with the two typical systems of exfoliation. Most grains exhibit polysynthetic twinning (Fig. 1a).

The "ivory cream marble" (MC) has various shades of brown. In thin section oolites and fossils are observed which occupy between $60-70 \%$ of the total area. The sample present fractures which are filled with coarsely crystalline calcite. It presents intraclasts basically micritic accompanied by pisolites and nummulitides (Fig. 1 b). This sample can be classified as a biomicritic limestone, although it is marketed as a marble.

The "Estepa limestone" (CE) is dull white in color with a compact structure, although some porosity is observed. No crystals or cracks are visible in hand samples, although there are poorly defined areas of brown inclusions. In thin section, a great abundance of oolites, approximately $75 \%$ of the slide, and remnants of gastropods and some crystals of sparite filling cracks or pores are observed (Fig. 1c). This rock can be defined as biosparitic limestone. 
a)

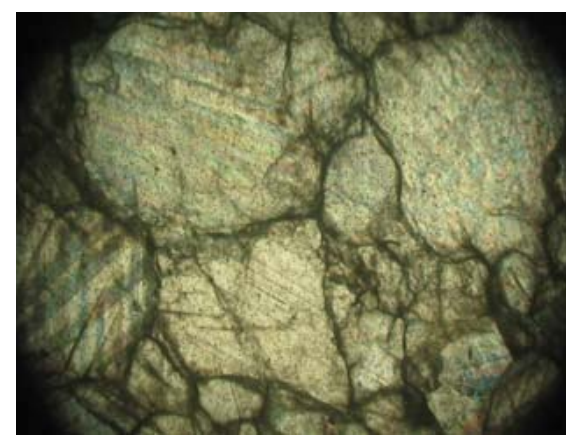

b)

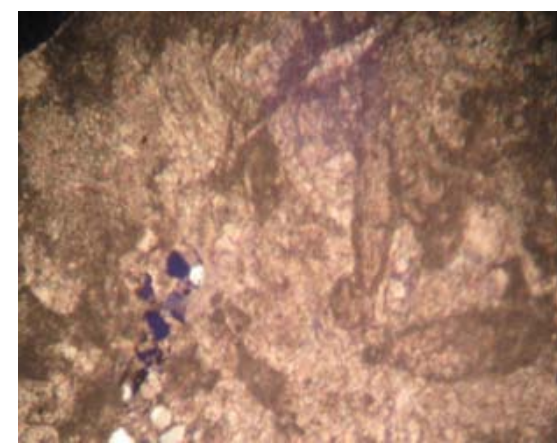

c)

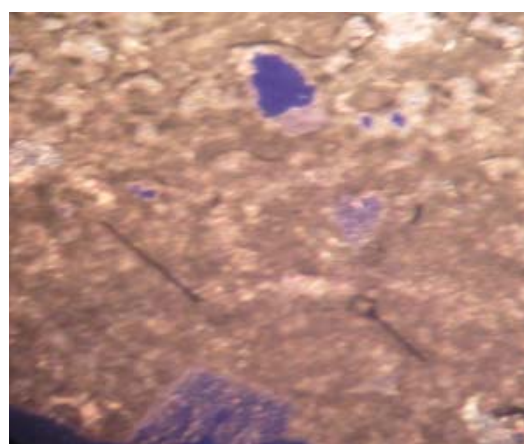

Figure 1: Thin section photographs corresponding to: a) "Macael White marble" (MB); b) "Ivory cream marble" (MC) and c) "Estepa limestone" (CE)

According to the chemical analysis, the major components of the three rocks are calcium oxide and volatiles lost due to the decomposition of $\mathrm{CaCO}_{3}$ during ignition. They are typical for a carbonate rock. With regard to the minor elements, the presence of aluminium and silicon in MC, magnesium in the $\mathrm{MB}$ and iron in $\mathrm{CE}$ are notable (Table 3).

The XRD patterns of the three rocks contain high peaks $(\mathrm{Ca})$ representative of calcite, the major mineral component. Other peaks reveal dolomite (Do) and quartz (Q) as minor minerals (Fig. 2).

\subsection{Technical Test Results}

The white marble (MB) and the cream marble (MC) produced the highest values of bulk and real density (Table 3) and lowest water absorption capacity. The Estepa limestone (CE) had the greatest porosity (open and total) and the largest water absorption capacity. The sample with the highest percentage of open pores is obviously the one with the greatest water absorption, and vice-versa.

The cream marble (MC) is the most resistant to compression, but the white marble (MB) tests produced the smallest coefficient of variation (Table $3)$. This statistic $\left(\sigma_{\mathrm{n}-1}=\right.$ standard deviation) gives an idea of the homogeneity of the material and thus the reliability of its application as structural material. The compressive strengths of all the natural stone materials always exceed the values of the typical concrete used in construction, which are between 25 and $50 \mathrm{MPa}$ [17].

The gain in the mass during the salt crystallization test is proportional to initial porosity of the samples (Table 3). i.e. Estepa limestone is visually the less degraded sample by the salt crystallization but its gain of mass is the higher.
During the frost resistance test, the white marble (MB, Fig. 3a), was not visually altered. However, the cream marble (MC) and Estepa limestone (CE) exhibited changes that can be classified as type 3 [12] (Figs. 3b and 3c). During the sixth cycle, MC presented cracks of variable length and width between 1 and $2 \mathrm{~mm}$. In subsequent cycles, the cracks grew in size. For each of the "marbles", the polished face exhibited fewer cracks. The alteration of the Estepa limestone (CE) was different, instead of cracks, holes of variable size (up to $3 \mathrm{~mm}$ in diam.) were formed during cycle 10 and later.

To check the effect of freezing cycles on open porosity, additional tests not included in the standard method were performed on two specimens of $\mathrm{MC}$ and CE. In these two rocks, there was a different increase in the open porosity, due to the deterioration produced by the freeze/thaw cycles. Open porosity increased almost $100 \%$ for the MC samples (Table 3). This is due to the composition and texture of the rock, in which the fossil clasts have different thermal expansion coefficients and, above all, different water absorption potential. However $\mathrm{CE}$, which was the material that showed greater initial porosity and a more homogeneous microstructure, did not show a significant change in porosity following the freezing test.

$\mathrm{SO}_{2}$ alteration is more severe with the more concentrated solution (solution A) with the attack forming a thin layer of calcium sulfate on the surface closest to the solution. In more dilute solution (Solution B), the affected areas are distributed throughout the piece, although not uniformly. For the MB test, the deposit actually covers the whole sample. The polished face is least attacked, the deposits are mainly on the edges and cracks of the 
Table 3: Technological test results

\begin{tabular}{|c|c|c|c|}
\hline & MB & MC & CE \\
\hline Bulk density $\left(\mathrm{gr} / \mathrm{cm}^{3}\right)$ & $2.686\left(\sigma_{n-1}=0.0126\right)$ & $2.662\left(\sigma_{n-1}=0.0149\right)$ & $2.430\left(\sigma_{n-1}=0.0168\right)$ \\
\hline Density $\left(\mathrm{gr} / \mathrm{cm}^{3}\right)$ (mean of two values) & 2.721 & 2.703 & 2.640 \\
\hline Open porosity (wt \%) & $0.119\left(\sigma_{n-1}=0.011\right)$ & $0.283\left(\sigma_{n-1}=0.023\right)$ & $3.473\left(\sigma_{n-1}=0.383\right)$ \\
\hline Porosity (wt \%) & 1.313 & 1.538 & 7.981 \\
\hline $\begin{array}{l}\text { Coefficient of water absorption by capillarity } \\
\left(\mathrm{g} / \mathrm{m}^{2} \mathrm{~s}^{0.5}\right)\end{array}$ & 0.209 & 0.225 & 8.680 \\
\hline Uniaxial compressive strength (MPa) & $65.35\left(\sigma_{n-1}=16.20\right)$ & $104.00\left(\sigma_{n-1}=37.91\right)$ & $71.48\left(\sigma_{n-1}=27.221\right)$ \\
\hline Expectative lower strength (MPa) & 63.67 & 97.43 & 64.18 \\
\hline Standard variation coefficient & 0.25 & 0.36 & 0.38 \\
\hline $\begin{array}{l}\text { Salt crystallization resistance (wt \% mass incre- } \\
\text { ment) }\end{array}$ & -0.25 & 0.47 & 0.89 \\
\hline $\begin{array}{l}\text { Frost resistance: } \\
\text { Grade of deterioration } \\
\left(n^{\circ} \text { of cycle }\right)\end{array}$ & 0 & $\begin{array}{l}3 \\
(7)\end{array}$ & $\begin{array}{c}3 \\
(11)\end{array}$ \\
\hline Open porosity results after frost resistance test & 0.119 & 0.615 & 3.350 \\
\hline $\begin{array}{l}\text { Resistance to aging by } \mathrm{SO}_{2} \text { action: } \\
\text { Weight increment after aging with solution } \mathrm{A}\end{array}$ & 0.077 & 0.098 & 0.493 \\
\hline Weight increment after aging with solution $B$ & 0.037 & 0.053 & 0.096 \\
\hline $\begin{array}{l}\text { Resistance to aging by thermal shock (wt \% } \\
\text { mass increment) }\end{array}$ & 0.02 & 0.02 & 0.00 \\
\hline
\end{tabular}

specimens. The sample most affected is $\mathrm{MB}$, and $\mathrm{CE}$ the least affected visually. $\mathrm{MB}$ and $\mathrm{MC}$ even lost the polishing on one of their faces.

Because of the support of the specimens for the attack by the most concentrated $\mathrm{SO}_{2}$ dissolution was a plate of galvanized steel, the altered materials showed the crystallization of zinc sulphate on the surface, preventing the attack of the dissolution on the entire piece, as in the case of the dissolution "B" test, in which test the support was ceramic. This caused apparently a greater attack at the bottom of the pieces in the case of the solution "A", when in fact it is a deposit of zinc sulphate as shown in the images of $\mu$-XRF (Fig. 4). It is to be noted that there is a thin layer of calcium sulfate on the surface of the probe (barely detectable visually), on which has precipitated a visible layer of zinc sulphate, mainly located in areas close to contact with the plate of galvanized steel and not throughout the surface of the sample (Fig. 3c).

Moreover, the study by $\mu$-XRF also confirmed the importance of polishing of the faces in the case of marble, both white and cream, because although the salts crystallizing the entire surface of the probes, the concentration of sulphates is much lower in the case of the face polished (Fig. 5).

Finally whereas the test results of resistance to thermal shock may indicate that two of the samples (white marble and Estepa limestone) have not suffered alterations remarkable or likely to influence their use, however the marble cream has suffered a clear deterioration (Fig. 3b), which is less apparent in the face polished. 


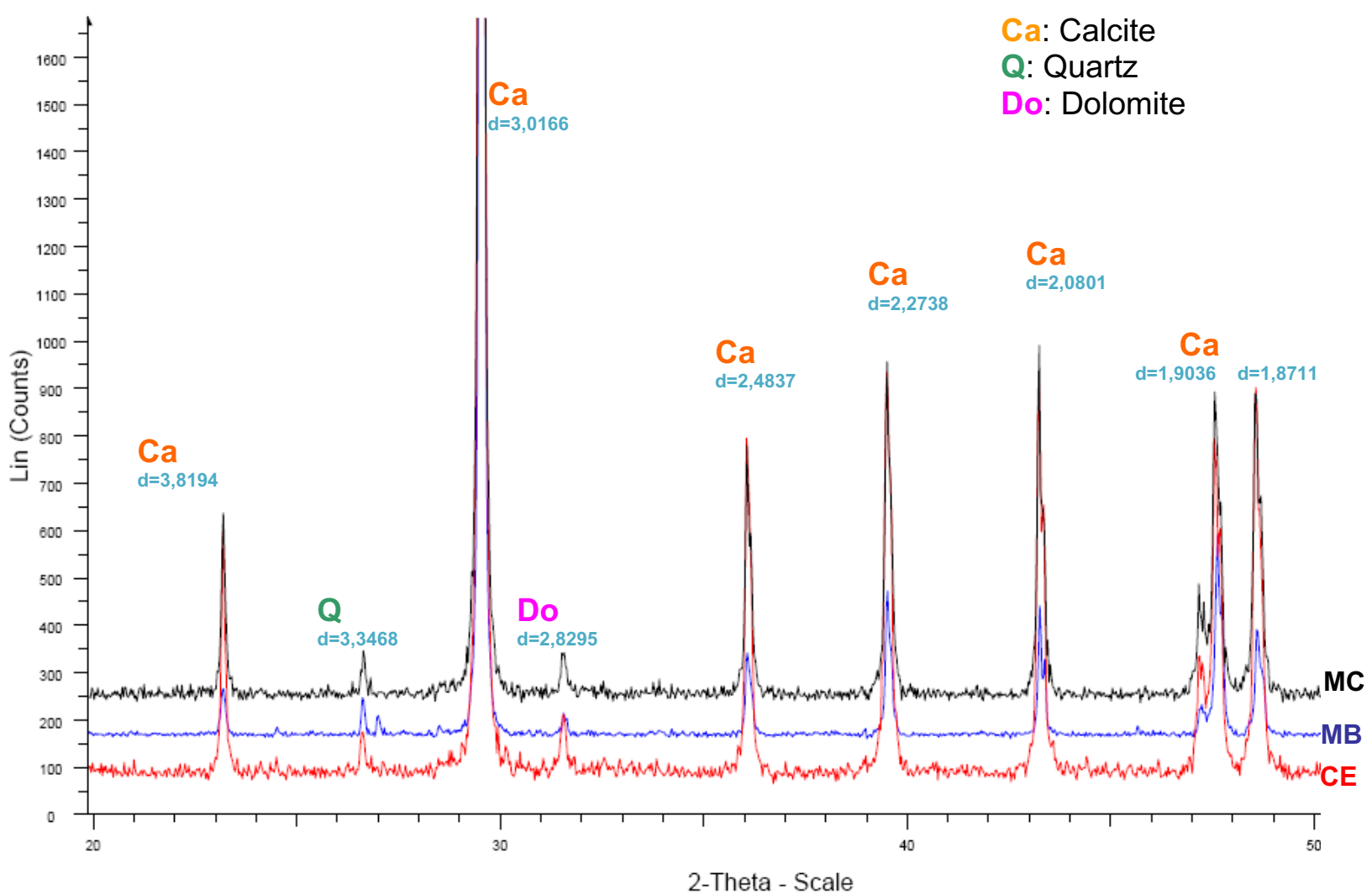

Figure 2: X-ray pattern of "Macael White marble", "Ivory cream marble" (MC) and "Estepa limestone" (CE)

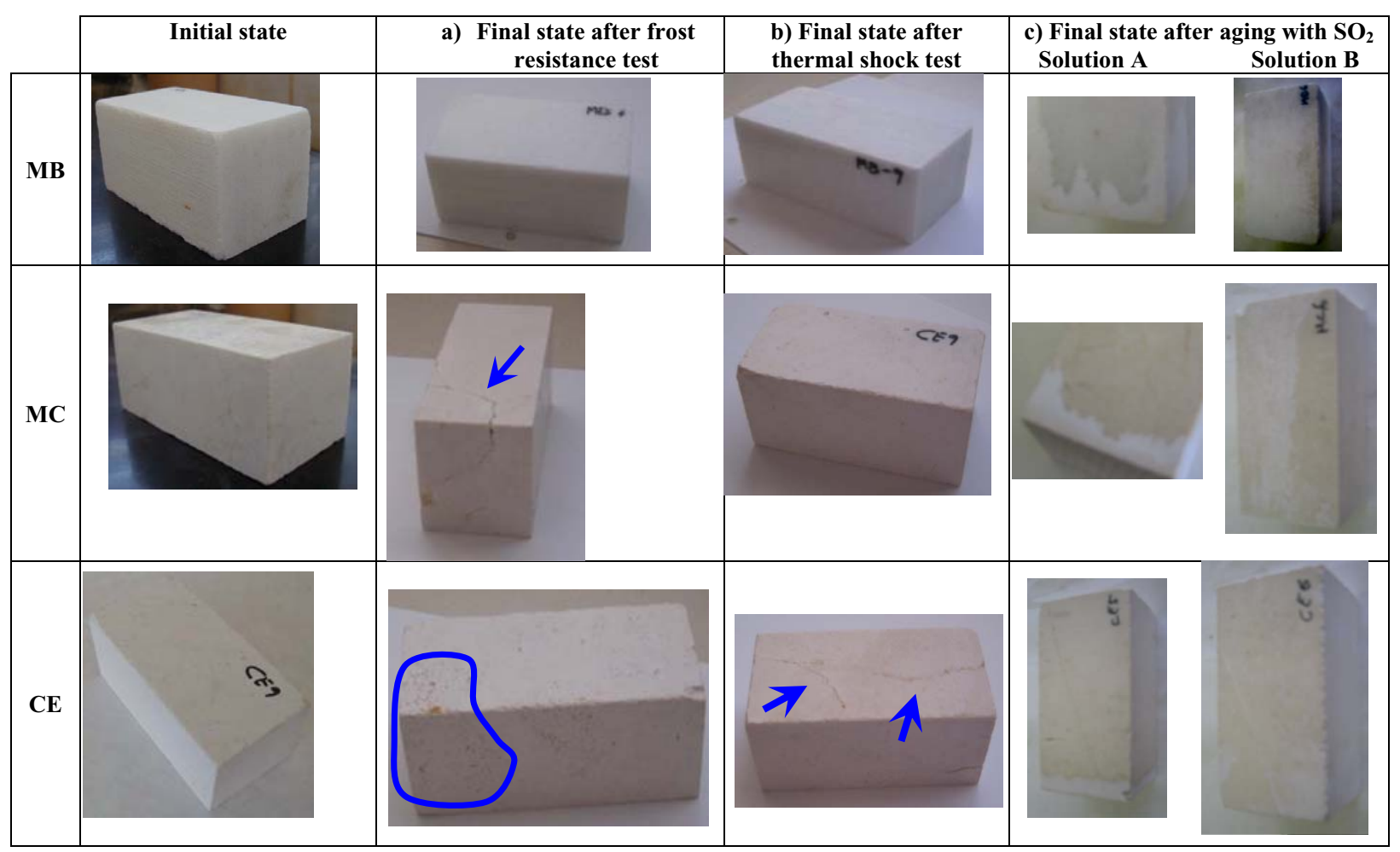

Figure 3: Comparison between initial state and final state of the samples, after: a) frost resistance test, b) thermal shock test and c) aging by $\mathrm{SO}_{2}$ action 


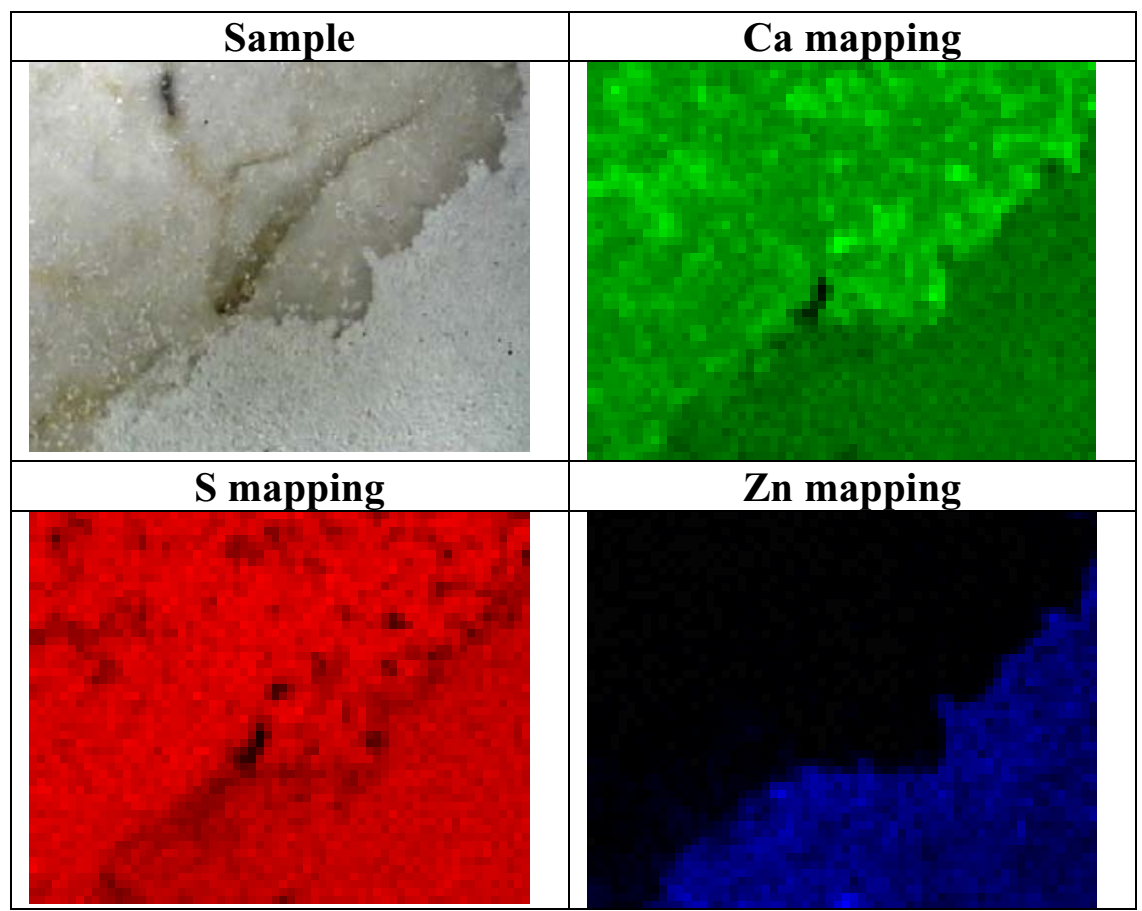

Figure 4: Mapping, by $\mu F R X$, of chemical elements (Ca, $S, Z n)$ on the surface of "Ivory cream marble" (MC).

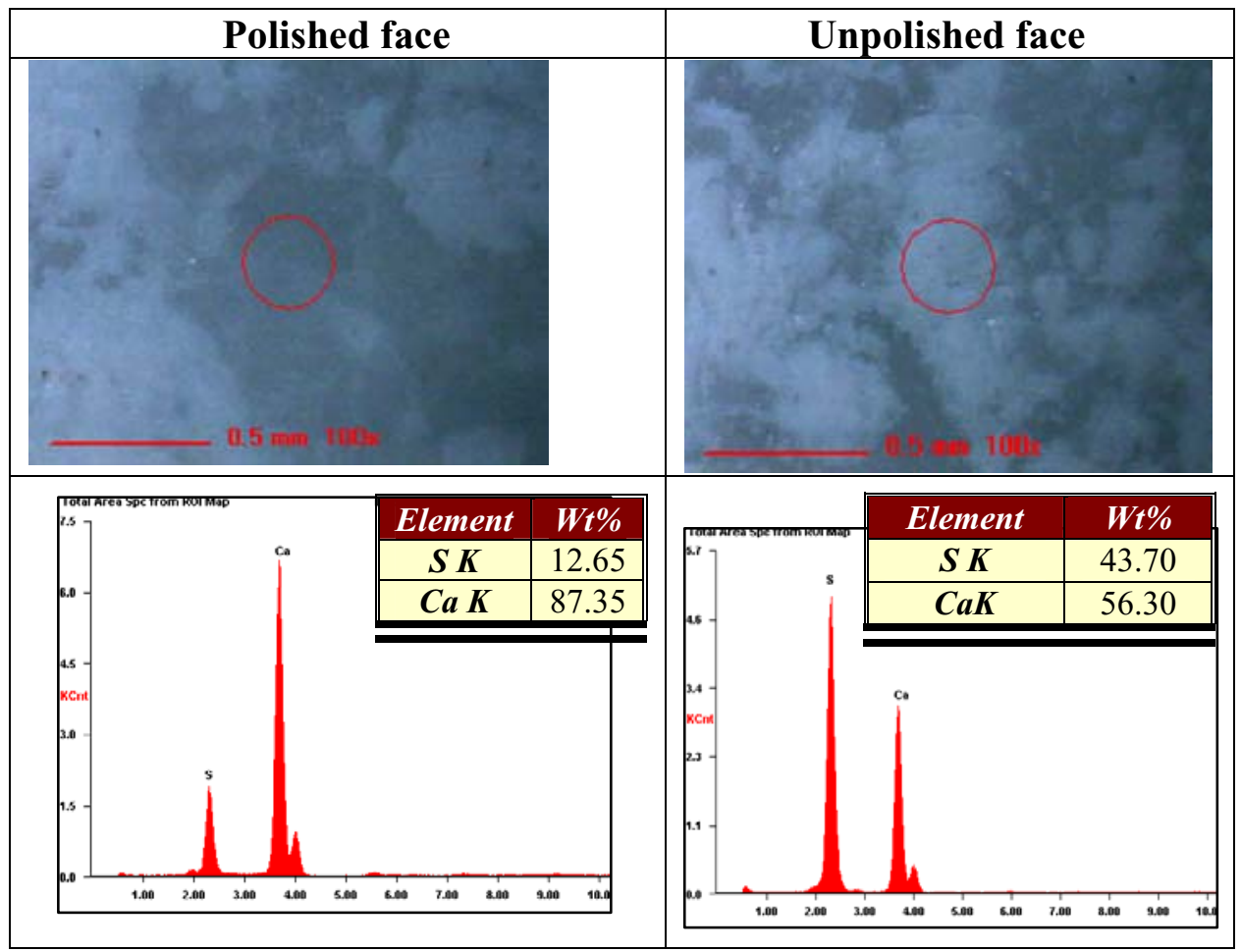

Figure 5: Comparison of $\mathrm{S}$ content, determined by $\mu \mathrm{FRX}$, between polished and unpolished face of "Macael White marble" (MB). 


\section{Discussion and Conclusions}

As is deduced from the results of technological tests, there is a direct relationship between the open porosity and the coefficient of water absorption by capillarity, as well as the behavior with regard to some of the tests of degradation, such as ice/thaw, crystallization of salts and thermal shock.

The existence of polished faces in white and cream marbles had great influence on the outcome of some tests, noting that act as protection against the aging by $\mathrm{SO}_{2}$, in the trial of frost, and in the crystallization of salts.

Moreover, the results of uniaxial mechanical resistance obtained are far from those data provided commercially (13.66 MPa for MB, 13.63 MPa for $\mathrm{MC}$ and $86.4 \mathrm{MPa}$ for CE) [18]. This test implies a great variability in the results depending on the sample, on the quarry where was sampled or on the bank of where it was extracted. Therefore, it would seem appropriate to specify the coefficient of variation always together with the mechanical resistance $[19,20]$.

With regard to the potential uses of each of the stones tested, the Estepa limestone could not be used in pavements due to its porosity and the impossibility of polishing.

In the case of outdoor use, the cream marble should be ruled out under extreme weather, because of their bad behavior with the frost and the thermal shock.

It is noteworthy on the other hand, from the ornamental point of view, the good behavior of the Estepa limestone in the tests of aging to $\mathrm{SO}_{2}$, and crystallization of salts, where the visual appearance has not changed, nor its color, compared to the degradation that has been observed in the other two samples. However, according to the regulations, it would be the Estepa limestone the rock that worse has behaved because there was a greater increase of weight in this test, but this value does not really correspond to the behavior of the rock with such aging, because the appearance after degradation is better than in the other cases.

From the structural point of view is the white marble to choose, especially for outdoor uses, because of its excellent behavior with regard to the frost and thermal shock. Although this material shows a lower mechanical resistance to the compression, it presents a minor coefficient of variation; therefore the value is more reliable than in the case of the other samples with observed defects that can result in a value of resistance considerably lower than expected. In addition, the possibility of polishing the outer surfaces, serve as protection against pollutants external.

In relation to the analysis of Standards, from this study we can conclude that despite the fact that the information on the texture of the rock is one of the most important aspects to forecast its behavior during the degradation, the legislation does not specify on how many test pieces must conduct the textural study in order to define the texture of the rock. This aspect is considered essential because in some rock types the texture is quite variable, and it should be explored in a number of samples to cover the various textural aspects that may occur.

On the other hand, as there is no correlation between the test results of the mechanical resistance to compression and trade data provided by enterprises [19] it seems that the Norms should require that the commercial data were presented with the coefficient of variation. Although were recently updated three Standards UNE 1926:2006 [10], UNE 771-6:2006 [21], UNE 14066:2011 they does not still include this requirement.

On the other hand the number of cycles to those who undergo the test in the case of the tests of crystallization of salts and thermal shock, makes the results can be away from the reality described in the bibliography [22, 23, 24] among others, which makes necessary to amend the parameters of the tests. In addition, the results obtained can be completed, for example, as it has been done in this work, checking the variation of the porosity of the rock after the aging, which gives us an idea of the internal deterioration undergone.

All the above justifies a revision of the current Normatives in the sense to give more importance to the textural study of the rock, and to amend the parameters of testing and the valuation of the results.

\section{Acknowledgment}

The authors appreciated the facilities provided by the X-ray Laboratory of the Center for Research, Technology and Innovation at the University of Seville (CITIUS), where they have done part of the analysis; and to Prof. Fco. Javier Alejandre (Dpto. de Construcciones Arquitectónicas, University of Seville), by the facilities to the determination of uniaxial compressive strength. This study has been partially supported by the Andalucía Government through the Research Group "Applied Mineralogy" (RNM135). Authors are grateful to Prof. Ray E. Ferrell for the revision of the manuscripts. 


\section{References}

1. Roc Máquina: La piedra Natural de España 2007, Ed. Reed Business information, p. 544 (2007)

2. M. Bustillo Revuelta, J.P. Calvo Sorrando, Materiales de construcción, Fueyo Editores, Madrid (2005)

3. UNE 12440:2001, Natural Stone. Denomination criteria, AENOR (2001)

4. UNE 12670:2003, Natural Stone, Terminology, AENOR (2003)

5. UNE12407:2007, Natural Stone Test Methods. Petrographic examination, AENOR (2007)

6. A. Castro Dorado, (1989), Petrografía básica. Textura, clasificación y nomenclatura de rocas, Editorial Paraninfo, Madrid, p. 143 (1989)

7. F.H. Chung, Quantitative interpretation of $X$-ray diffraction patterns of mixtures, Ed. II: Adiabatic principle of X-ray diffraction analysis of mixtures, In: Journal of Applied Crystallography, v 7, 526-531 (1974)

8. UNE 1936:2007, Natural Stone Test Methods, Determination of real density, and apparent density, and total and open porosity, AENOR (2007)

9. UNE 1925:1999, Natural Stone Test Methods. Determination of water absorption by capillarity, AENOR (1999)

10. UNE 1926:2006, Natural Stone Test Methods. Determination of compressive strength, AENOR (2006)

11. UNE 12370:1999, Natural Stone Test Methods. Determination of resistance to salt cristallization, AENOR (1999)

12. UNE 12371:2011, Natural Stone Test Methods. Determination of frost resistance, AENOR (2011)

13. UNE 13919:2003, Natural Stone Test Methods. Determination of resistance to aging by $\mathrm{SO}_{2}$ action in presence of humidity, (2003)

14. UNE 14066:2003, Natural Stone Test Methods. Determination of resistance to aging by thermal shock (2003)

15. R.L. Folk, Practical petrographic classification of limestone, In: American Association of Petroleum Geologists Bulletin, K V43, pp 1-38 (1959)
16. P. Ortiz, E. Mayoral, M.A. Guerrero, E. Galán, Caracterización petrográfica y geoquímica de las calizas de la Sierra de Estepa (Sevilla) y evaluación de la calidad técnica como material de construcción, In: Estudios Geológicos, 51, p 183-296 (1995)

17. EHE-08, Instrucción de hormigón estructural, Real Decreto 1247/2008 de 18 de julio, 2008

18. J. Avellaneda, Una visión de la actualidad de la construcción en Piedra, In: Anuario 1999 Piedras Naturales de España (1999)

19. D. Benavente D, Propiedades fisicas y utilización de rocas ornamentales, In: García del Cura M Á y Cañaveras J C, Editores. Seminarios de la Sociedad Española de Mineralogía. ITGE, SEM y Universidad de Alicante, Volumen 2, Utilización de Rocas y Minerales Industriales, p 123-153 (2006)

20. A. Bernabeu, Utilización de rocas como pavimentos, In: García del Cura M Á y Cañavares J C, Editores. Seminarios de la Sociedad Española de Mineralogía. ITGE, SEM y Universidad de Alicante. Volumen 2, Utilización de Rocas y Minerales Industriales, p 247-266 (2006)

21. UNE-EN 771-6:2006, Especificaciones de piezas para fábrica de albañilería, Parte 6: Piezas de piedra natural (2006)

22. E. Galán, M.A. Guerrero, M.A. Vázquez, F. Maert, F. Zezza, Marble weathering: Relation between ultrasonic data and macroscopic observations. The case of the columns of the Court of the Lions at the Alambra in Granada, Spain, In: Decrovez D, Chamay S and Zezza F, Editores. The conservation of monuments in the Mediterraneum Basic. Proc. 2nd International Symposium. Genève, p 193-204 (1991)

23. E. Galán, The influence of temperatura changes on stone decay, In: Zezza F, Editor. Weathering and air polution. C.U.M. University School Monument Conservation, p 119-129 (1991)

24. Ortiz Calderón $\mathrm{M}^{\mathrm{a}}$ del Pilar, Influencias del entorno ambiental en los procesos de degradación de la piedra de la Catedral de Cádiz. Aproximación teórica y recomendaciones para la conservación, Tesis Doctoral, Universidad de Sevilla (1998) 

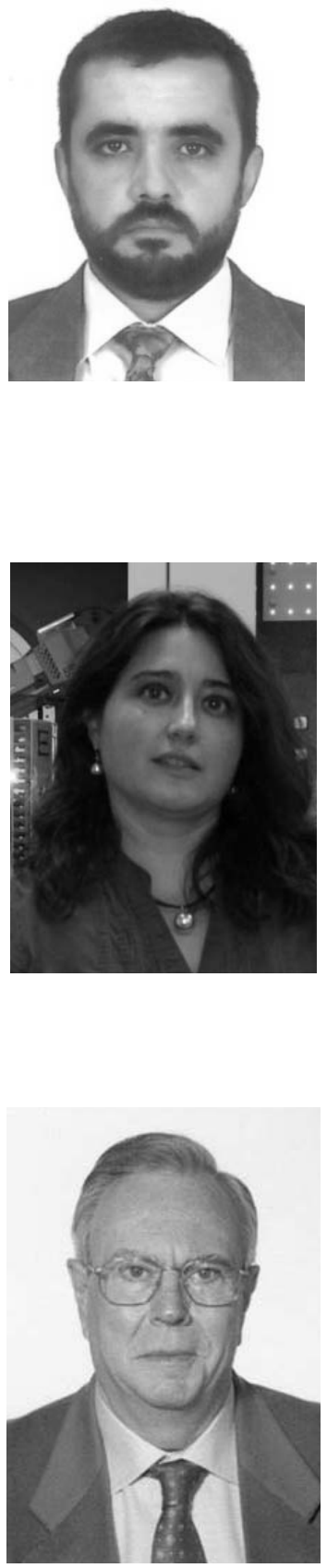

Eng. Francico J. Ortega. Master Degree University of Seville (Materials Engineer), 2008. Bachelor Degree University of Seville (Materials Engineer), 2007. Master Degree in Prevention and Control of Environmental and Laboral Risks, UNED 2004. Technical architect from 1998 at the Officer of the Army Corps of Engineers of the air. Present is member of the Research Group "Applied Mineralogy", where is preparing his Ph. D. about the "Conservation degree of the Central Building of the University of Seville (Tabaco Factory)".

Dr. Patricia Aparicio. Ph. D. University of Seville (Chemistry) 1996; M.S. University of Seville (Chemistry) 1991. Assistant Professor (1997-2003) and Associate Professor of Crystallography and Mineralogy at the University of Sevilla, 2003-present. Visiting Research Scientist: Lousiana State University in Baton Rouge, USA (1998 and 2000); Institute of Ceramic Research (IRTEC), in Faenza, Italy (2000); Universitá degli Studi di Bologna, in Bologna, Italy (2006) and University of Indiana, in Bloomington, USA (2007). Leader of courses on X-ray diffraction and Lecturer in specialized courses on clay mineralogy. Author or co-author of 45 papers published in scientific journals and book chapters, most of them on clays and clay minerals, soil pollution, carbon capture sequestration. Co-author of two patents to improve kaolin properties during industrial treatment, and $\mathrm{CO}_{2}$ capture in waste construction materials, respectively. Member of 28 government or industrial research projects on clays and the environment. Leader of research projects on carbon capture sequestration by clays and silicate materials. Chair of the X-ray Laboratory at the General Research Service (CITIUS) at the University of Seville (2008-present).

E-mail: paparicio@us.es

Prof. Dr. Emilio Galán. Ph. D. University of Madrid (Geology) 1972; M.S. University of Granada (Geology) 1966. Assistant Professor (University of Granada and Madrid), Associate Professor (Extremadura and Zaragoza Universities), and Full Professor of Crystallography and Mineralogy at the University of Sevilla, 1982-present. Research Scientist at the National Council of Research (CSIC) in Madrid, 1973-76. Visiting Research Scientist, University of Indiana, at Bloomington (1980). Professor at the Universities of Modena and Bologna (Italy) (1998 and 2000 respectively). Lecturer at about 30 Universities and Scientific Institutions in Spain and other countries. Author or co-author of more than 200 papers published in scientific journals, most of them on clays and clay minerals, other industrial minerals and rocks (diatomite, barite, talc, magnesite, graphite, gems), monument conservation and soil pollution. Various books or book chapters on mineralogy, kaolin, special clays (mainly palygorskite-sepiolite), mineralogy and cultural heritage conservation. Editor or co-editor of various Proceedings and books on clay. Supervisor of $22 \mathrm{Ph}$ Doctoral Thesis. Leader of various national and european projects on clay research, the environment, and monument conservation.

Received July 20, 2011 
Brought to you by | Biblioteca de la Universidad de Sevilla Authenticated 